\title{
Research on the Role of Urban Culture in Urban Sculpture Creation
}

\author{
Hongwu $\mathrm{Li}^{1, \mathrm{a}}$ \\ ${ }^{1}$ Department of sculpture, Academy of Fine Arts, Zhengzhou University Zhengzhou, China 450000 \\ a625526223@qq.com
}

Keywords: urban culture; urban sculpture creation; role.

Abstract. Urban culture is the soul, symbol and essence of a city. It can fully demonstrate the connotation and history of a city. Urban sculptures are signs of a city, record development culture, integrate the history, culture and stories in a special form and are of certain significance. They not only enrich urban residents' spiritual enjoyment to a certain extent, but also represent the culture of a city and even a country. For this end, this article attempts to analyze the important role of urban culture in urban sculpture creation.

\section{Introduction}

With the advance of economy and society, spiritual civilization has received increasing concern in modern people' s life. The position of urban culture in urban construction has been gradually enhanced. It has become an integral part of urban construction. The creation technique and creation style of urban sculptures, as iconic buildings of a city, will directly reflect connotations of urban culture. As a materialized representation of urban culture after precipitation and a people-oriented environmental art, it plays a crucial role in urban construction.

\section{The Practical Significance of Urban Culture and Urban Sculptures}

1.The practical significance of urban culture

(1)The definition of urban culture . Urban culture refers to civilizations that are gradually spread and inherited by people in a city in long-term living environment and living process, or a generic term of cultural patterns and living habits co-created by people based on the geographic location and natural environment of a city. Urban culture is an important embodiment of modern spiritual civilization, which can adjust itself according to people' s living habits and social activities and provide certain convenience for their daily life, study and work. It is a kind of codes of conduct and ethics abided by modern people. Although academic circles haven' t made a clear definition of urban culture, the concept of urban culture has been rooted in the mind of modern people, as an important manifestation of modern people’ s psychological state and artistic achievement [1]. Tab. 1 shows the composition of urban culture:

Tab. 1 The Composition of Urban Culture

\begin{tabular}{|c|c|}
\hline $\begin{array}{l}\text { Material } \\
\text { Culture }\end{array}$ & $\begin{array}{l}\text { Buildings, roads, communication facilities, residences, } \\
\text { water sources, all kinds of goods and green environment, etc. }\end{array}$ \\
\hline $\begin{array}{l}\text { Institutional } \\
\text { Culture }\end{array}$ & Family system, economic system, political system, etc. \\
\hline $\begin{array}{l}\text { Spiritual } \\
\text { Culture }\end{array}$ & $\begin{array}{l}\text { Knowledge, belief, art, ethics, law, custom, all abilities and } \\
\text { habits acquired by people. }\end{array}$ \\
\hline
\end{tabular}

(2)The significance of the existence of urban culture. Urban culture is an important embodiment of spiritual civilization during urban construction and a kind of social activities of modern people to adapt to natural environment and social environment. It is improved with the progress of era and change of thoughts. At present, with gradual improvement of modern people' s economic level, their desire for spiritual civilization has gradually been strengthened. The significance of urban culture in social development has gradually been revealed. All of modern people wish to create an innovative and cohesive urban culture, so as to satisfy their pursuit for spiritual civilization. Urban culture is the 
most valuable form of life created by urban residents, which not only enhances the overall ethos of a city, but also improves ecological environment and humanistic environment [2] and further promotes the steady development of socialist spiritual civilization and harmonious society. Tab. 2 shows the main content of urban culture:

Tab. 2 The Main Content of Urban Culture

\begin{tabular}{|c|c|c|c|c|c|}
\hline Clothing & Food & Housing & $\begin{array}{l}\text { Transp } \\
\text { ort }\end{array}$ & Language & $\begin{array}{l}\text { Entertainm } \\
\text { ent }\end{array}$ \\
\hline \begin{tabular}{l}
\multicolumn{2}{c}{ Dressing } \\
style and \\
characteristic \\
clothing, etc.
\end{tabular} & $\begin{array}{l}\text { Eatin } \\
\text { g habits } \\
\text { and } \\
\text { special } \\
\text { cuisine, } \\
\text { etc. }\end{array}$ & \begin{tabular}{l}
\multicolumn{1}{c}{ Living } \\
environment, \\
architectural \\
style and \\
living habits, \\
etc.
\end{tabular} & $\begin{array}{l}\quad \text { Travel } \\
\text { mode and } \\
\text { vehicle, } \\
\text { etc. }\end{array}$ & $\begin{array}{l}\quad \text { Dialect } \\
\text { and } \\
\text { characteristic } \\
\text { language, etc. }\end{array}$ & $\begin{array}{l}\text { Leisure } \\
\text { facility, } \\
\text { recreational } \\
\text { mode and } \\
\text { leisure time, } \\
\text { etc. }\end{array}$ \\
\hline
\end{tabular}

(3).The practical significance of urban culture

Urban sculptures are iconic buildings of a city. Different types of urban sculptures represent different meanings. Some urban sculptures play a decorative and beautifying role, while others are created to inherit urban culture. Whichever type of sculptures is an integral part of the city and has different missions. Urban sculptures occur in various places, such as squares, parks and roofs. They are all seating positions of urban sculptures and important landmarks of a city. Urban sculptures are an integral part of urban construction. It is epochal, historic, humanistic, regional and symbolic, etc. There are various types, too. Common sculptures include memorial urban sculptures, ornamental urban sculptures and iconic urban sculptures, etc. Urban sculptures not only inherit urban culture, but also beautify and add luster to the city. They receive high attention from modern people [3].Tab. 3 shows the main types of urban sculptures:

Tab. 3 Main Types of Urban Sculptures

\begin{tabular}{cl}
\hline Thematic Urban Sculpture & $\begin{array}{l}\text { To mainly reflect urban history, trend of } \\
\text { era and people' s ideal, etc. }\end{array}$ \\
\hline Memorial Urban Sculpture & $\begin{array}{l}\text { To commend and eulogize characters and } \\
\text { events that make significant contributions } \\
\text { to the country and nation in history } \\
\text { No specific theme and content, to } \\
\text { ornament the city and beautify the } \\
\text { environment }\end{array}$ \\
Iconic Urban Sculpture & $\begin{array}{l}\text { Urban sculptures that have an explanatory } \\
\text { function } \\
\text { Tecorative Urban Sculpture }\end{array}$ \\
& $\begin{array}{l}\text { To arrange different types of sculptures in } \\
\text { the form of exhibition for people to } \\
\text { appreciate }\end{array}$ \\
\hline
\end{tabular}

\section{A Study on the Influence of Urban Culture on Urban Sculpture Creation}

When studying the influence of urban culture on urban sculpture creation, we mainly start from two aspects: material and non-material. The material aspect of urban culture mainly refers to urban environment, creation materials and creation technology, while the non-material aspect mainly refers to the spiritual influence. From the material aspect, in the process of urban sculpture creation, creators must form a prototype in their mind according to seating position, to ensure that sculptures complement with surrounding environment, instead of simply playing an ornamental role. More importantly, they should coordinate and coexist. Meanwhile, creators also need to choose appropriate materials for sculpture creation, according to the environment in seating positions. Make sure that sculptures can be preserved for a long time, give full play to the important role of nature and maximize the actual effect of urban sculptures [4]. 
From the non-material aspect, modern people not only satisfy material demands, but also need to guarantee rich spirit. Both the history and spirit of urban culture produce a different influence on urban sculpture. Urban culture is not the same in different cities. Created urban sculptures vary, too. First of all, the creation of urban sculpture mustn' t destroy ecological environment of a city. When determining seating position, we should associate with the surrounding environment. Secondly, according to different seating positions, the meanings expressed by urban sculptures also differ. For example, sculptures seated in governments, plazas and stations, etc. must be of a practical significance, seize modern people' s psychology, fully demonstrate the connotations of urban culture and give play to the important role of iconic buildings, rather than simply playing a beautifying role. On the other hand, the creation of urban sculpture should also be combined with local customs, be educative and beneficial for modern people' $s$ life and entertainment [5]. Fig. 1 shows different types of urban sculptures.

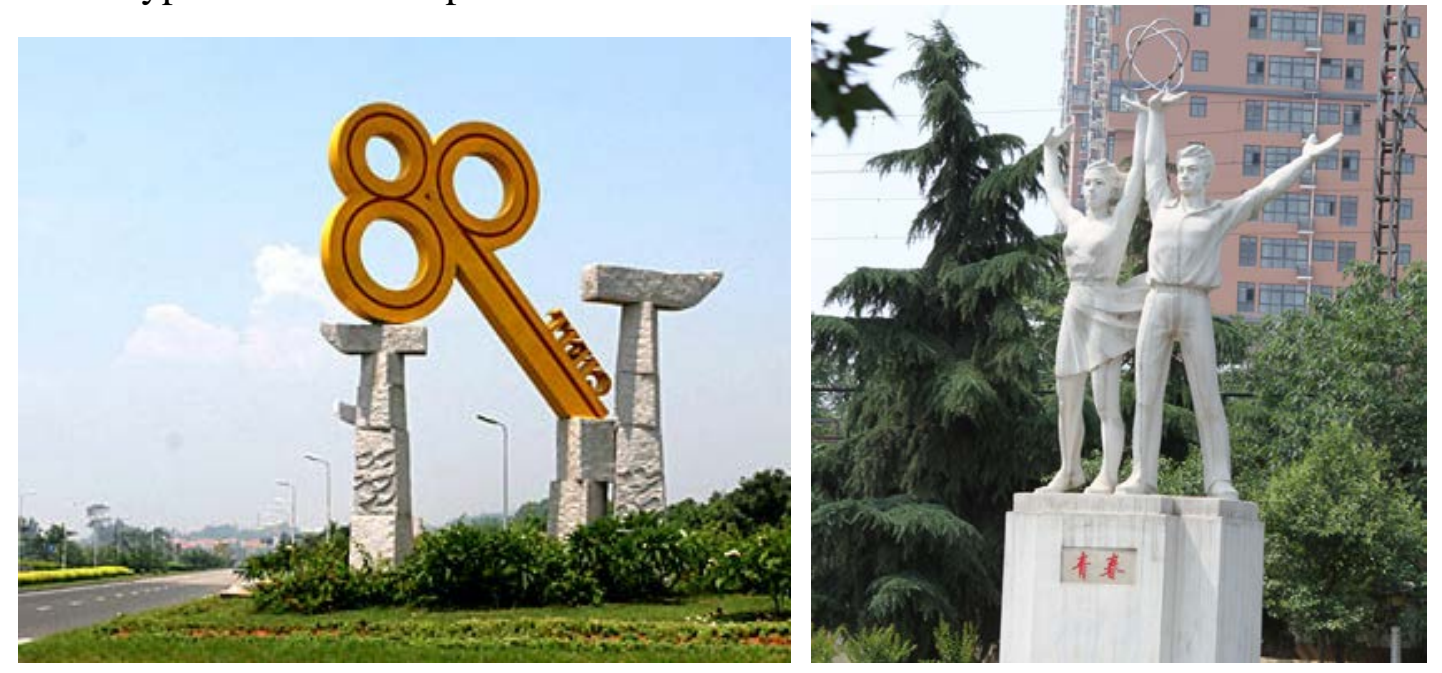

Fig. 1 Different Types of Urban Sculptures

\section{Conclusion}

From the above analysis, the creation of urban sculptures, as iconic buildings in a city should incorporate the content of urban culture and be inherited as a spiritual ballast during urban construction. The creation form of urban sculptures, as an important carrier in the inheritance process of urban culture, has a great impact on modern spiritual civilization. Urban sculpture creators should make an analysis, combining urban culture with regional characteristics, enhance the vitality of urban sculptures and promote the personalized and stylized development of urban sculptures.

\section{References}

[1]Jane Zheng. Contextualizing public art production in China: The urban sculpture planning system in Shanghai[J]. Geoforum, 2017:89 - 101.

[2]Jung T H, Lee J, Yap M H T, et al. The role of stakeholder collaboration in culture-led urban regeneration: A case study of the Gwangju project, Korea[J]. Cities, 2015, 44:29-39.

[3]Muthoni Ngotho, Robert Fincham, Nevil Quinn. Government, business and the public: The role of environmental education in creating sustainable urban places[J]. Environmental Education Research, 2004, 10(3):313-329.

[4]Comunian R. Rethinking the Creative City: The Role of Complexity, Networks and Interactions in the Urban Creative Economy[J]. Urban Studies, 2010, 48(6):1157-1179.

[5]Oliver M D. Geography, Race, and Class: A Case Study of the Role of Geography at an Urban Public University[J]. American Journal of Education, 1998, 106(Volume 106, Number 2):273-301. 